\section{Cliffrose Reproduction after Pinyon-Juniper Control $^{1}$}

\section{CLAY Y. MCCULLOCH ${ }^{2}$}

Research Biologist, Arizona Game and Fish Department, Tempe, Arizona.

\section{Highlight}

Age classes determined by ring counts showed that reproduction of cliffrose (Cowania mexicana) did not increase after bulldozing a sparse stand of pinyon and juniper trees in northern Arizona.

Pinyon (Pinus edulis Engelm.) and juniper (Juniperus osteosperma (Torr.) Little) trees have been controlled by pushing with bulldozers to improve forage for livestock and mule deer (Odocoileus hemionus) on parts of the North Kaibab Plateau of northern Arizona. A special aim of the tree eradication was to increase production of cliffrose (Cowania mexicana D. Don.) browse. The evergreen shrub is among the important foods of deer on winter range. For many years, degree of twig use on cliffrose was viewed as an indicator of hunting pressure needed to control the deer herd. Increased stand density of cliffrose has not been generally obvious after tree control, although shrub reproduction and survival rates conceivably could rise after potential competition from trees was reduced. Changes in these rates should be reflected in age composition of a cliffrose stand. This note reports age classes of a cliffrose population after eradication of a sparse stand of pinyon-juniper.

\section{Methods}

Basal stem sections were collected on the North Kaibab area in October 1966 from 169 cliffrose plants, which were the entire cliffrose population growing on 50 circular plots of 0.01 acre $\left(40.5 \mathrm{~m}^{2}\right)$ each. The plots were systematically spaced in a rectangular grid which encompassed 4 acres (1.6 ha), arbitrarily located where a sparse stand of pinyonjuniper (15 trees/acre $=37$ trees $/$ ha) was uprooted by bulldozers in 1955. Cross section surfaces of the cliffrose specimens were polished by sanding and annual growth rings were counted.

\section{Results}

The shrub specimens with intact centers showed no increase in cliffrose regeneration in the first 11-year period after tree eradication (Fig. 1). Instead of appearing disproportionately large, the cliffrose age class established since tree control was smaller than some of the older classes. More than half of the collected specimens had partial stem rot. All but one of the rotted population pre-dated tree eradication and thus were not indicative of cliffrose survival rates following pinyon-juniper control.

Results support the view that tree control should be deferred on parts of deer ranges where pinyon-juniper stands are sparse (Fig. 2). There was no apparent tendency toward

${ }^{1}$ Contribution of Federal Aid Project W78, Arizona Game and Fish Department. A. C. Crilley and N. G. Woolsey examined the stem specimens. Received December 30, 1970.

${ }^{2}$ Present address is Research Biologist, Arizona Game and Fish Department, Fredonia, Arizona.

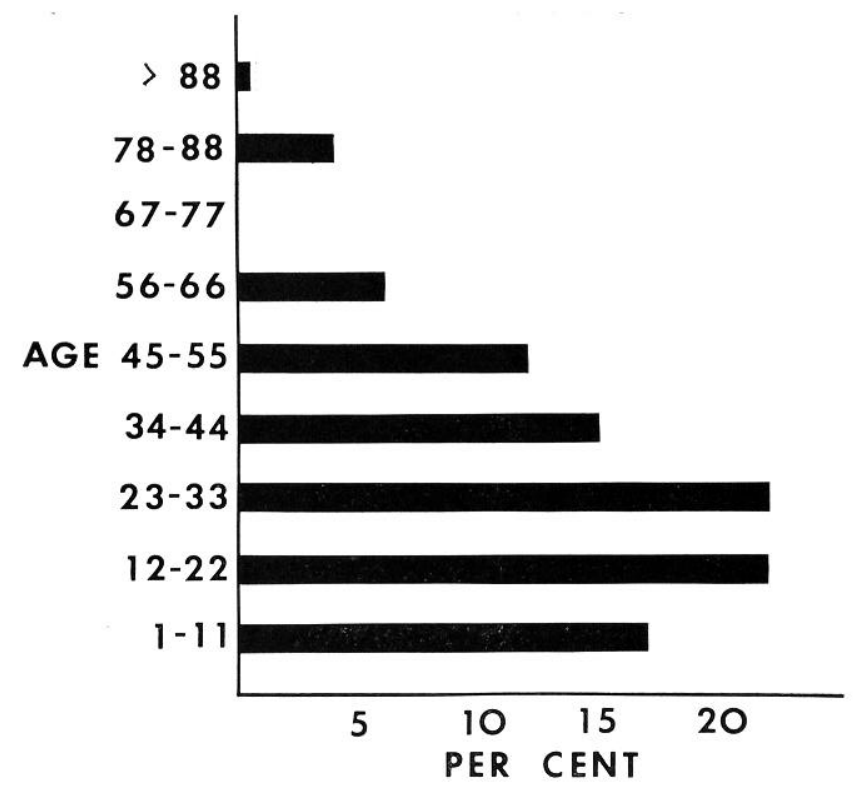

Fig. 1. Age composition (years) of cliffrose group 11 years after pinyon-juniper trees were bulldozed. ( $\mathrm{N}=73$ specimens with stem centers intact)

gains in cliffrose stand density 11 years after tree control. Thickening of the cliffrose population might be anticipated many years later, but this potential should be weighed against values of scattered clumps of trees for winter shelter and emergency browse sources. An earlier report noted a general increase in cliffrose browse production, presumably due to stimulated crown growth on shrubs established prior to pinyon-juniper eradication (McCulloch, 1966). Casual inspection of North Kaibab sites indicated good potential to increase cliffrose populations by bulldozing dense woodland $(>100$ trees/acre), but this was not systematically investigated.

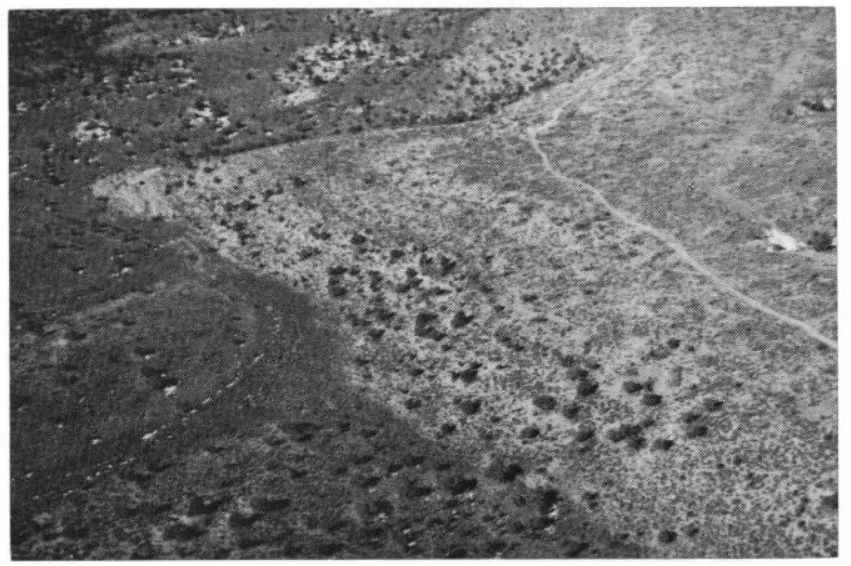

Fig. 2. Sparse pinyon-juniper stand, untreated (left) and bulldozed (upper right).

\section{Literature Cited}

McCulloch, C. Y. 1966. Cliffrose browse yields on bulldozed pinyon-juniper areas in northern Arizona. J. Range Manage. 19:373-374. 